\title{
The Relationship of the Duration of Social Media Instagram Usage and Student's Eating Behavior in University of Sumatera Utara, 2019
}

\author{
Selvi Karmila ${ }^{1}$, Evawany Y. Aritonang ${ }^{2}$, Etti Sudaryati ${ }^{3}$ \\ 1,2,3 Faculty of Public Health, Universitas Sumatera Utara, Medan, Indonesia \\ Email: selvikarmila21@yahoo.com
}

\begin{abstract}
:
The development of technology and culinary tourism has led to the high enthusiasm of social media users to bring up various Instagram culinary accounts that promote food. Food recommendations provided by food bloggers can be information, references in choosing food. The average duration of social media usage in Indonesia in 2018 is 3 hours 23 minutes a day. Exposure to food information on Social media instagram raises problems in choosing foods for students who are not concerned with the nutritional content of food that causes changes in eating behavior. This study aims to analyze the relationship of the duration of social media Instagram usage and student's eating behavior in University of Sumatera Utara. This study was an observational study using a cross-sectional design. The population in this study were undergraduate students at University of Sumatera Utara, with sample of 344 students. The data collection tool uses a questionnaire. Bivariate analysis using the Chi-Square statistical test. The results showed that the duration of social media Instagram usage among respondents was categorized high ( $\geq 3$ hours / day) as much as 55.8 percent. Bivariate analysis shows that there is a significant relationship of the duration of social media Instagram and eating behavior ( $p$ $<0.05)$. Students are expected to be able to limit themselves in using social media Instagram and are advised to consume balanced food. We recommend that the media such as Instagram culinary accounts can insert health messages as a food reference.
\end{abstract}

Keywords:

duration; Instagram; eating behavior; students

\section{Introduction}

The development of information and communication technology in the era of globalization is happening very fast, with the development of information and communication technology society will be increasingly easy to connect with other people in getting information quickly, accurately and precisely. The impact of advances in information and communication technology is characterized by increasing popularity in the use of social media that continues to grow. The results of a survey conducted by We are social and Hootsuite are social media platform agencies from the UK and Canada stating that in January 2019 active users of social media in Indonesia were 150 million or reaching 56 percent of the population. The amount from the previous survey in 2018 was around 130 million or 48 percent of the total population (Riyanto, 2019).

Instagram is an application that is used to share photos and videos that users may take photos, take videos, use digital filters, and then share them with other social networking services, one of them to their own Instagram. Instagram was created by Kevin Systrom and Mike Krieger, a Brazilian entrepreneur on October 6, 2010. Instagram is one of the largest social media users currently in the community, with 800 million users from around the world (Etherington, 2017). Instagram ranked seventh as the most social media user in Indonesia in 
2015 (Indonesian Internet Service Providers Association, 2015). In addition, quoted from the beritagar, in January 2018 Indonesia is the country with the most instagram users after the United States with the number, 110 million, followed by Brazil where 57 million and 55 million instagram users are active in Indonesia (Techinasia, 2018).

The development of food trends has ushered in a new culture such as culinary tourism. The development of this technology is utilized by food bloggers as a medium for sharing information. A food blogger is a title given to someone who writes, takes photos and videos about food which is then uploaded to a blog such as Social media instagram (Goenawan, 2015). Instagram can make it easier to find information related to food and can influence users of the Instagram to follow the recommendations given by food bloggers. Some social media instagram users who are looking for information related to food and visit the desired restaurant, therefore do not be surprised if the recommendations given by food bloggers can directly affect consumers' intentions to visit recommended culinary places.

Social media instagram usage is very easy, if you already have the Instagram application and have an account then you can use it to search for food-related information on explore or search by typing the desired Instagram name, then follow (culinary) accounts that are considered interesting then each follower can directly see the post on their Instagram homepage. This food blogger shares food photos with complete information making users use the Instagram application as a source of information. Medan is a city famous for food heaven. This makes the connoisseurs or business people look for ways to make culinary in the city of Medan increasingly recognized by the community not only in the local community but also people outside the city of Medan. The more sophisticated technology, everyone can access anything, including to share photos about culinary. Social media instagram in addition to being a food information media for the community especially culinary lovers and can also help promote a culinary place to be better known by the community.

The existence of an Instagram culinary account that promotes a variety of foods can influence students in choosing food and eating behavior that is not in accordance with the guidelines for balanced nutrition. The interaction between students and the Instagram culinary account is the basis for researchers to examine the relationship between the duration of Social media instagram usage and eating behavior of students at the University of Sumatera Utara in 2019. This study aims to know the relationship of the duration of Social media instagram usage and student's eating behavior in University of Sumatera Utara, 2019.

\section{Research Methods}

This type of research is a quantitative observational study using a cross-sectional study design. The population in this study were all undergraduate students at North Sumatra University. The study program was taken using cluster random sampling technique. The number of clusters was obtained based on the cluster table (Lut, 1982), namely as many as 16 study programs out of 46 study programs at the University of North Sumatra. The sample size in each study program was obtained using a large sample table of Isaac and Michael with an error level of five percent (Sugiyono, 2010: 128), so the sample size in this study was 344 students. Samples in each study program in the study were taken by purposive sampling. The data in this study are the duration of Social media instagram usage taken by interviewing respondents using a research questionnaire while eating behavior data using FFQ. Data analysis techniques in this study were univariate and bivariate analyzes. 


\section{Discussion}

\subsection{Univariate Analysis}

\section{a. Characteristics of Respondents}

The results showed the distribution of the overall respondents netted in the study were more 21 years old as many as 92 people $(26.7 \%)$. The age of respondents in this study ranged from 18-25 years.

Table 1. Distribution of Respondents by Age

\begin{tabular}{crr}
\hline Age & $\mathbf{N}$ & $\mathbf{\%}$ \\
\hline 18 & 24 & 7,0 \\
19 & 30 & 8,7 \\
20 & 42 & 12,2 \\
21 & 92 & 26,7 \\
22 & 83 & 24,1 \\
23 & 40 & 11,6 \\
24 & 18 & 5,3 \\
25 & 15 & 4,4 \\
\hline Total & 344 & 100 \\
\hline
\end{tabular}

The results showed that more than half of the respondents 68.3 percent were female and 31.7 percent were male.

Table 2. Distribution of Respondents by Gender

\begin{tabular}{lcc}
\hline Gender & $\mathbf{N}$ & $\mathbf{\%}$ \\
\hline Male & 109 & 31,7 \\
Female & 235 & 68,3 \\
\hline Total & 344 & 100 \\
\hline
\end{tabular}

\section{b. Duration of Social Media Instagram Usage}

The duration category of Social media instagram usage can be divided into two, namely high ( $\geq 3$ hours / day) and low (1-3 hours / day). Based on Table 3 below the distribution of respondents that the duration of Social media instagram usage in this study is categorized high, namely ( $\geq 3$ hours / day) as much as 55.8 percent and categorized as low (1-3 hours / day) as much as 44.2 percent.

Table 3. Distribution of Respondents by Duration of Use of Social Media Instagram

\begin{tabular}{lcc}
\hline Duration & $\mathbf{N}$ & $\mathbf{0}$ \\
\hline High ( $>3$ hours/day) & 192 & 55,8 \\
Low (1-3 hours / day) & 152 & 44,2 \\
\hline Total & 344 & 100 \\
\hline
\end{tabular}

\section{c. Eating Behavior}

Eating behavior in this study is categorized into two including balanced eating behavior and unbalanced eating behavior. The average score of eating behavior is 2.18 with a standard deviation of 0.988 . These results are categorized based on the mean as a cut of point, which is balanced eating behavior if the respondent's value is more than 2.18 and the category is unbalanced if the respondent's value is less than equal to 2.18. Based on Table 5, the distribution of unbalanced eating behavior among respondents was 64.8 percent and 35.2 percent of respondents had balanced eating behavior. 
Table 4. Distribution of Respondents Based on Eating Behavior

\begin{tabular}{lcc}
\hline Eating Behavior & $\mathrm{N}$ & $\%$ \\
\hline Not Balanced & 223 & 64,8 \\
Balanced & 121 & 35,2 \\
\hline Total & 344 & 100 \\
\hline
\end{tabular}

The assessment of eating behavior according to the guidelines for balanced nutrition can be seen in Table 5. Based on the staple food guidelines vary as much as 81.4 percent, consuming only one type of staple food in the past month namely white rice alone by 18.6 percent. Respondents consume a source of protein divided into two, namely animal protein sources and vegetable protein sources. Most respondents had consumed protein varied from vegetable sources and animal side dishes 66.0 percent, while the remaining 34.0 percent only consumed protein sources from animal side dishes or only vegetable side dishes. Based on general guidelines on balanced nutrition, it is required to increase consumption of vegetables and fruits, most respondents do not consume vegetables and fruits every day. Only 41.0 percent of respondents often consume vegetables and fruits every day and the majority of respondents 59.0 percent only consume one of them vegetables or fruits, or consume vegetables and fruits less than one times a day. Based on general guidelines balanced nutrition limits risky foods such as sweet, salty, and fatty foods. Most of the respondents 67.7 percent often consume risk foods with daily frequency and 32.3 percent consume risk foods on a weekly frequency. Some foods that were frequently consumed by respondents such as fried foods, instant noodles, junk food, ice cream, fried chicken (fast food).

Based on the total scores of the four indicators in this study, it can be seen that the results of this study were as many as 64.8 percent of respondents had unbalanced eating behavior and balanced eating behavior of 35.2 percent.

Table 5. Distribution of Respondents' Eating Behavior in the Last One Month

\begin{tabular}{|c|l|c|c|c|}
\hline & & & $\mathbf{N}$ & $\mathbf{\%}$ \\
\hline \multirow{2}{*}{1.} & Variation of Staple Foods & Varied & 280 & 81,4 \\
& & Unvaried & 64 & 18,6 \\
\hline \multirow{2}{*}{2.} & Variation of Protein & Varied & 227 & 66,0 \\
& Consumption & Unvaried & 117 & 34,0 \\
\hline \multirow{2}{*}{3.} & Frequency of Consumption & Often & 141 & 59,0 \\
& of Vegetables and Fruits & Rarely & 203 & 41,0 \\
\hline \multirow{2}{*}{4.} & Food Frequency at Risk & Often & 233 & 67,7 \\
& & Rarely & 111 & 32,3 \\
\hline
\end{tabular}

\subsection{Bivariate Analysis}

Relationship between the duration social media Instagram usage with eating behavior. The duration of use of social media is an independent variable that is analyzed in relation to the dependent variable namely eating behavior. Based on Table 6 shows that as much as 70.3 percent of respondents with a high duration of social media Instagram usage experienced unbalanced eating behavior. Bivariate analysis test results using the chi-square test showed there was a significant relationship between the duration ofsocial media Instagram usage with eating behavior $(\mathrm{p}=0.023$; $\mathrm{p}<0.005)$. 
Britain International of Humanties and Social Sciences (BIoHS) Journal

ISSN: 2685-3868(Online), 2685-1989(Print)

Vol. 2, No. 1, February 2020, Page: 289-295

Table 6. Bivariate Analysis Results between the Duration of Social media instagram usage with Eating Behavior

\begin{tabular}{|c|c|c|c|c|c|c|}
\hline \multirow{3}{*}{ Duration } & \multicolumn{4}{|c|}{ Eating Behavior } & & \\
\hline & \multicolumn{2}{|c|}{ Balanced } & \multicolumn{2}{|c|}{ Unbalanced } & \multicolumn{2}{|c|}{ Total } \\
\hline & $\mathbf{N}$ & $\%$ & $\mathbf{N}$ & $\%$ & $\mathbf{N}$ & $\%$ \\
\hline High & 57 & 29,7 & 135 & 70,3 & 192 & 100 \\
\hline Low & 64 & 42,1 & 88 & 57,9 & 152 & 100 \\
\hline
\end{tabular}

\section{Conclusion}

It can be concluded in this study that the duration of Social media instagram usage on students is categorized high ( $\geq 3$ hours / day) which is as much as 55.8 percent. There is a relationship of the duration of social media Instagram usage and eating behavior.

From the conclusion above, the suggestions are: For institutions the results of this study can be used as additional information to carry out a program or health promotion activities and socialization related to balanced eating behavior through social media owned by the campus such as the student government of the University of Sumatera Utara (PEMA USU). In addition, the activities that can be carried out are making Information and Education Communication Media (IEC) in the form of posters and establishing partnerships that are carried out in coordination with various government institutions such as local health workers in an effort to increase knowledge of nutrition problems and their solutions and delivery of balanced nutrition messages. For students to be able to limit themselves in using social media Instagram by filling their free time with useful activities such as joining organizations, reading books in the library. It is expected to improve themselves in consuming food to fit the needs and have a balanced eating behavior. The industry and the media are expected to increase attention for the food industry and the media such as food bloggers to be invited to participate in promoting and providing information about food by inserting health messages such as about healthy and nutritious food as a food reference. For researchers, further research can be conducted to look further at the relationship of Instagram culinary accounts usage on health behavior and nutritional status of students.

\section{References}

Alfredo, B., Swandi, I. W., Hosana, M., Visual, D. K., Seni, F., Petra, U. K., \& Siwalankerto, J. (2015). Perancangan media panduan wisata kuliner khas indonesia khususnya warung makan kaki lima yang berpotensi di Surabaya. Jurnal Desain Komunikasi Visual, 2(1).

Andi, D,. Riyanto. (2019, 30 Januari). Hootsuite We Are Sosial: Indonesia digital report 2019. Diakses: 02 Februari 2019, dari http://andi.link/hootsuite-we-are-social-indonesiadigitalreport-2019/

Anggraini, S. (2012). Faktor lingkungan dan faktor individu hubungan dengan konsumsi makanan pada mahasiswa asrama universitas depok (Tesis, Universitas Indonesia). Diakses dari lin.ui.ac.id/file?file $=$ digital $/ 20315565$

Aulia, I.A (2018). Pengaruh media sosial terhadap pergerakan sosial masyarakat di Timur Tengah, Journal 2(3).

Azlina, A. (2014) Pengaruh aktivitas instagram terhadap sikap mahasiswi pengguna instagram di Bandung: studi pada fashion blogger. (Tesis yang tidak dipublikasikan). Fakultas Komunikasi dan Bisnis, Universitas Telkom.

Badan Penelitian dan Pengembangan Kesehatan. (2018). Riset Kesehatan Dasar dan Kementrian Kesehatan Republik Indonesia. Diakses dari 
http:/www.libang.kemkes.go.id/

Badan Penelitian dan Pengembangan Kesehatan. (2013). Studi Diet Total Survei Konsumsi Makanan Individu dan Kementrian Kesehatan Republik Indonesia. Diakses dari http:/www.libang.kemkes.go.id/

Chen, G. M. (2011). A uses and gratifications persepective on how active twitter use gratifies a need to vonnect with other. Computers in Human Behavior. Journal, 11(27),755-762.

Choudhury, M. De, Tech, G., \& Tech, G. (2016). Characterizing dietary choice, nutrition, and language in food deserts via social media. ISBN, 978-1- 4503. doi: 10.1145.2818048.2819956

Chuang, H. (2009). The rise of culinary tourism and its transformation of food cultures: the nation cuisine of Taiwan. The Copenhagen Journal , Asia Studies, 27(2), 78-90.

DeFleur, B., Rokeach. (1975). The procces and effect of communication. New York: Logman 3 rd Edition.

Dianastuti, W. A. (2015). Penggunaan instagram sebagai media promosi kuliner Kota Semarang studi pada komunitas Online @jakulsemarang. Jurnal UNRI, 5(3) 1-9.

Dila, Y. P. (2013). Faktor-faktor yang berhubungan dengan perilaku makan pada remaja putri di SMA Negeri 10 Padang. Jurnal UNAND, 67 (1). 1-24.

Dirmahasiswa. (2013, 15 July). Data mahasiswa USU. Diakses 25 Juli 2019, dari http://dirmahasiswa.usu.ac.id/

Evans, R., Norman, P., \& Webb, T. L. (2017). Using temporal Self-regulation Theory to understand healthy and unhealthy eating intentions and behaviour. Appetite, 116, 357364. doi:10.1016/j.appet.2017.05.022

Goenawan, G. (2015). Co-creation communication pengguna instagram dalam foodstagram di Surabaya. Jurnal E-Komunikasi, 3(1), 1-10.

Hanifati, A. N. (2015). The impact of food blogger toward consumer's attitude and behaviour in choosing restaurant. International Journal of Humanities and Management Science, 3 (2320-4044), 1-12.

Hidayatun. U. (2015). Pengaruh intensitas penggunaan media sosial dan dukungan teman sebaya terhadap perilaku konsumtif pada siswa SMA Muhammadiyah 3. Jurnal . 4(10), 45-50.

Hizni, A. (2017). Gizi dewasa. ilmu gizi. teori dan aplikasi. Jakarta: EGC.

Judhita, Christiany. (2011). Hubungan penggunaan situs jejaring sosial facebook terhadap perilaku remaja di kota Makassar. Jurnal, 1(21), 73-82.

Kementrian Kesehatan RI, 2014. Pedoman Gizi Seimbang 2014. Diakses 23 Juni 2019 dari https://pergizi.org/pedoman-gizi-seimbang-2014-terbaru/

Khoirunisa, N.I (2017). Media sosial instagram, perilaku makan dan status gizi studi pada kelompok usia dewasa muda di Kabupaten Slema Yogyakarta (Tesis yang tidak dipublikasi). Fakultas Kesehatan Masyarakat UGM, Yogyakarta.

Lenhart, A. (2010). Social media \& mobile internet use among teens and young adults. A Project of the Pew Research Center. Diakses 21 Maret 2018 dari https:// files.eric.ed.gov/fulltext/ED525059.pdf

Ma, G. (2015). Food, eating behavior, and culture in Chinese society. Journal of Ethnic Foods, 2(4), 195-199. doi:10.1016/j.jef.2015.11.004

Marta, R.F., \& William., Denise. M. (2016). Studi terpaan media pemasaran melalui postingan instagram. analisis eksplanasif pada komunitas food blooger. Jurnal 8(1), 62-82.

Mayvita, I., Taqwa. (2018). Intensitas penggunaan media sosial instagram stories dengan kesehatan mental. Jurnal 8(1), 22-35.

Perttula, M. (2013). social media as a means of tourism marketing text analysis of finnish tour operators visibility in social media (Thesis, degree programme in tourism). Diakses dari https://scholar.google.co.id/ 
Pew Internet \& American Life Project. (2001) Teenagers life online: the rise of the instantmessage generation anf the internet's impact on friendship and family reletionship. Washington D.C.: Pew Internet \& American Life Project. Diakses 29 maret 2019 dari http://www. pewresearch.org

Quick, V., Wall, M., Larson, N., Haines, J., \& Neumark-sztainer, D. (2013). Personal, behavioral and socio-environmental predictors of overweight incidence in young adults : 10-yr longitudinal findings Journal, 10(1), 1. Doi :10.1186/1479- 5868-10-37

Sangadji., Etta M dan Sopiah. (2013). Perilaku konsumen: Pendekatan praktis disertai himpunan jurnal penelitian (Edisi- 1).Yogyakarta: Andi.

Sendjadja, S. D. (2002). Pengantar komunikasi. Universitas Terbuka: Jakarta.

Stefani. R. P. (2017). Hubungan terpaan komunikasi pemasaran kuliner pada akun media sosial instagram@kulinersby terhadap motvasi konsumen. Jurnal Unair. 7(3), 1-15.

Suwannapinunt, P., Sitthikraiwong, K., Nimitsukcharoen, P., Dollayanukloh, S., Puttiphaibool, T., Nattharika. (2013). social media usage related to food and beverages: an investigation of college students in Bangkok and metropolitan area. Proceedings of the 4 years International Conference on Engineering, Project, and Production Management. 2013720-733.

Tani, Y., Kondo, N., Takagi, D., Saito, M., Hikichi, H., Ojima, T., \& Kondo, K. (2015). Combined effects of eating alone and living alone on unhealthy dietary behaviors, obesity and underweight in older Japanese adults: Results of the JAGES. Appetite, 95, 1-8. doi:10.1016/j.appet.2015.06.005

Tenia, Hilda. (2017). Pengertian media sosial. Diakses 28 Januari 2019 dari http://www.kata.co.id/Pengertian/ Media-Sosial/879.

Vaterlaus, J. M., Patten, E. V, Roche, C., \& Young, J. A. (2015). Computers in Human Behavior \# Gettinghealthy: The perceived influence of social media on young adult health behaviors. Computers in Human Behaviour. Diakses 15 Januari 2018. 8(7), 151-157.

Wallis, J. (2015). The effects of social media on the body satisfaction of adolescent and young adult females. Kansas State University. Diakses dari http://krex.kstate.edu/dspace/bitstream/handle/2097/18945/juliawallis2015.pdf?sequence $=2$

Wahyuni, Sri. (2011). Hubungan faktor internal dan pola makan fast food dengan status gizi mahasiswa di Universitas Gadjahmada Yogyakarta. Diakses dari http:/ / etd.respository.ugm.ac.id/home/detail_pencarian/58066

Wate, J. T., Snowdon, W., Millar, L., Nichols, M., Mavoa, H., Goundar, R., Swinburn, B. (2013). Adolescent dietary patterns in Fiji and their relationships with standardized body mass index, 1-12. Int J Behav Nutr Phys Act, 9(10),45.doi:10.1186/1479-5868$10-45$

Wirjatmadi. W. (2012). Pengantar gizi masyarakat. Jakarta: Kencana Prenada Media Group.

World Health Organization. (2015). Healthy diet. Diakses http://www.who.int/news$\mathrm{room} /$ fact-sheet/detail/healty-diet 